Iana Carolina Maciel Franza

A Never-ending Plight for Authentic Love

\section{Intemational Institute
for Boonenergetic Analysis (Ed).}

Bioenergetic Analysis 2021 (31)

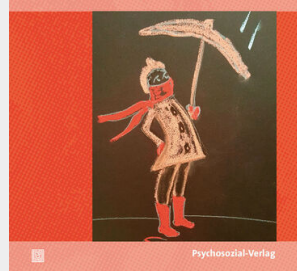

Bioenergetic Analysis

31. Volume, No. 1, 2021, Page 95-110 Psychosozial-Verlag

DOI: 10.30820/0743-4804-2021-31-95 
Reviewers for this issue:

Léia Cardenuto, Garry Cockburn, Maê Nascimento and M. Rosaria Filoni

Translators of abstracts for this issue:

Angelina Samartova (Russian), Claudia Ucros (French), Karin de Marval (Spanish), Maê Nascimento (Portuguese), Maria Rosaria Filoni (Italian), Thomas Heinrich (German) and Rebecca Jianpu Liu (Chinese)

Submissions for consideration for the next volume of Bioenergetic Analysis must be sent to Maê Nascimento (maenascimento@terra.com.br) between June $1^{\text {st }}$ and September $1^{\text {st }}$, 2021.

Bibliographic information of Die Deutsche Nationalbibliothek (The German Library) The Deutsche Nationalbibliothek lists this publication in the Deutsche Nationalbibliografie; detailed bibliographic data are available at http://dnb.d-nb.de.

2021 Psychosozial-Verlag, Gießen, Germany

info@psychosozial-verlag.de

www.psychosozial-verlag.de

\section{(C) $(1) \Theta$}

This work is licensed under the Creative Commons Attribution-NonCommercialNoDerivatives 4.0 International License (CC BY-NC-ND 4.0). This license allows private use and unmodified distribution, but prohibits editing and commercial use (further information can be found at: https://creativecommons.org/licenses/by-nc-nd/4.0/). The terms of the Creative Commons licence only apply to the original material. The reuse of material from other sources (marked with a reference) such as charts, illustrations, photos and text extracts may require further permission for use from the respective copyrights holder.

Cover image: Vincentia Schroeter, Umbrella girl (c) Vincentia Schroeter Cover design \& layout based on drafts by Hanspeter Ludwig, Wetzlar Typesetting: metiTec-Software, me-ti GmbH, Berlin, www.me-ti.de

https://doi.org/10.30820/0743-4804-2021-31

ISBN (PDF-E-Book) 978-3-8379-7809-4

ISBN (Print) 978-3-8379-8363-0

ISSN (Online) 2747-8882 • ISSN (Print) 0743-4804 


\title{
A Never-ending Plight for Authentic Love ${ }^{1}$
}

\section{Handling Schizoid Ambivalence}

\author{
Iana Carolina Maciel Franza
}

Bioenergetic Analysis • The Clinical Journal of the IIBA, 2021 (31), 95-110

https://doi.org/10.30820/0743-4804-2021-31-95

CC BY-NC-ND 4.0

www.bioenergetic-analysis.com

\section{Abstracts}

"Schiz" is a Latinized word-forming element that means split, division or cleavage. In German, the word schizoid, turned up in the 1920's meaning "resembling schizophrenia", from the combination of (gr.) schiz + (gr.) oeides, "like", form eidos, form or shape. In The Betrayal of the Body, The Language of the Body, and Bioenergetics, Dr. Lowen's works that most thoroughly teach us his views about the schizoid character structure, it becomes evident that the story of the schizoid split is a one of very early rejection and hostile hatred, culminating in profound, many times painfully misunderstood, inner torment. The following article offers some considerations about the schizoid structure illustrated by an analysis of clinical work with a client. Reflecting upon the theoretical proposal of how interaction, in this case, may be felt particularly as an oppressive inner ambivalence, this paper will present considerations about handling with a schizoid client in the therapeutic setting.

Keywords: schizoid, ambivalence, love, hostility, authenticity, therapeutic relationship

A infinita busca do amor autêntico. Lidando com a ambivalência esquizoide (Portuguese)

"Schiz" é um prefixo latino que significa divisão, cisão ou clivagem. Em alemão, a palavra esquizoide emergiu nos anos 1920 com o significado de "semelhante à esquizofrenia", da combinação de (Gk.) schiz + (Gk.) oeides- de oeidos "forma ou formato". É nos trabalhos do Dr. Lowen $O$ corpo traido, A linguagem do corpo e Bioenergéticaque podemos compreender profundamente sua concepção da estrutura de caráter esquizoide. Fica claro que a divisão esquizoide se refere à rejeição e ao ódio hostil precoces, culminando num

1 This Case Study won $1^{\text {st }}$ Prize for the IIBA Clinical Award at the $25^{\text {th }}$ IIBA Conference in Portugal, 2019. 
tormento interior profundo e, com frequência, dolorosamente mal compreendido. Este artigo oferece algumas considerações sobre a estrutura esquizoide, ilustrada pela análise de um estudo de caso. Ponderando, aqui, sobre a proposição teórica de como as interações podem ser particularmente sentidas como uma ambivalência interna opressiva, este artigo apresenta considerações sobre como lidar com um cliente esquizoide no ambiente terapêutico.

Una situación interminable para el amor autentico. Lidiando con la ambivalencia esquizoide (Spanish)

"Schiz_"es un prefijo derivado del latín que significa, escisión, división o clivaje. En alemán, la palabra esquizoide apareció en los años 1920 con un significado "semejante a la esquizofrenia", resultado de la combinación de (Gk.) schiz + (Gk.)-oeides- de oeidos "forma ou formato". En los trabajos de Lowen, La traición al cuerpo, El lenguaje del cuerpo y Bioenergética, podemos comprender a fondo su visión sobre la estructura del carácter esquizoide. Es evidente que la escisión esquizoide es resultado del rechazo y odio hostil precoces, culminando en un profundo, y frecuentemente mal comprendido, tormento interior. Este artículo plantea algunas consideraciones sobre la estructura esquizoide ilustrado por el análisis de un caso clínico. Reflexionando sobre la propuesta teórica de cómo interacciones, en esto caso, pueden ser sentidas particularmente como una opresiva ambivalencia interior, este trabajo presenta consideraciones sobre como lidiar con un paciente esquizoide en el encuadre terapéutico.

L'infinita condizione dell'amore autentico. Gestire l'ambivalenza schizoide (Italian) "Schiz" è un elemento di derivazione latina che nella formazione delle parole indica divisione, dissociazione o scissione. In tedesco, la parola schizoid, nel significato del 1920, significa "somigliante alla schizofrenia", dalla combinazione di schiz + oeides (forma). Dalle opere di Lowen Il tradimento del corpo, Il linguaggio del corpo e Bioenergetica possiamo comprendere più a fondo le sue opinioni sulla struttura del carattere schizoide. Risulta chiaro che la dissociazione schizoide deriva dal rifiuto precoce e da odio e ostilità che esitano in un profondo tormento interiore, spesso dolorosamente frainteso. L'articolo offre alcune considerazioni sulla struttura schizoide, illustrata dal lavoro clinico con un paziente. Riflettendo sulla ipotesi teorica che, in questi casi, l'interazione possa essere percepita come un'oppressiva ambivalenza interiore, l'articolo propone delle considerazioni sul modo di trattare un paziente schizoide nel contesto terapeutico.

\section{Un combat sans fin pour l'amour authentique. Gérer l'ambivalence schizoïde (French)}

"Schiz-" est une particule latinisée formant un mot qui signifie fente, division ou clivage. En allemand, le mot schizoïde, est apparu dans les années 1920, pour signifier "ressemblant à la schizophrénie", de la combinaison (Grec) schiz + (Grec) -oeides "comme", de eidos "forme ou aspect". C'est dans les ouvrages du Dr Lowen, Le corps bafoué, Le langage du corps et L'Analyse Bioénergétique, que nous pouvons le mieux connaître son point de vue 
sur la structure du caractère schizoïde. Il devient évident que la dissociation schizoïde est le résultat d'un rejet très précoce et d'une haine hostile, culminant en un tourment intérieur profond, et souvent douloureusement incompris. L'article suivant propose quelques considérations au sujet de la structure schizoïde illustrées par une analyse du travail clinique avec un client. En réfléchissant à la proposition théorique sur la manière dont les interactions, dans ce cas clinique, peuvent être ressenties en particulier comme une ambivalence intérieure oppressante, cet article présentera des recommandations pour l'abord d'un client schizoïde dans le cadre de la psychothérapie.

Der nie endende Kampf um authentische Liebe. Umgang mit schizoider Ambivalenz (German)

"Schiz-" ist eine latinisierte Vorsilbe, die Spaltung, Teilung oder Abspaltung bedeutet. Im Deutschen tauchte das Wort schizoid in den 1920er Jahren auf und bedeutet "der Schizophrenie ähnelnd", aus der Kombination von (gr.) schiz + (gr.) -oeides "wie" von eidos "Form oder Gestalt". In Dr. Lowens Werken Der Verrat am Körper, Körperausdruck und Persönlichkeit und Bioenergetik können wir am gründlichsten seine Ansichten über die schizoide Charakterstruktur kennenlernen. Es wird deutlich, dass es sich bei der schizoiden Spaltung um eine sehr frühe Ablehnung und Feindseligkeit handelt, die in einer tiefgreifenden und oft schmerzhaft missverstandenen inneren Qual gipfelt. Der folgende Artikel bietet einige Überlegungen zur schizoiden Struktur, die durch eine Fallanalyse illustriert werden. Ausgehend vom Exposé darüber, wie Interaktionen in diesem Fall besonders als bedrückende innere Ambivalenz empfunden werden können, werden in diesem Beitrag Implikationen zum Umgang mit schizoidem Klienten innen im therapeutischen Setting vorgestellt.

Бесконечная помолвка для подлинной любви: как обращаться с шизоидной амбивалентностью (Йана Каролина Масьель Франца) (Russian)

"Schiz-" - латинизированный элемент словообразования со значением "разделение, раскол, расщепление“. В немецком языке слово “шизоид“ появилось в 1920-х годах в значении "похожий на шизофрению“- как комбинация (греч.) schiz + (греч.) oeides "подобный“ (от eidos "форма или фигура“). Наиболее полно познакомиться с взглядами доктора Лоуэна на структуру шизофренического характера можно в его работах Предательство тела, Язык тела и Биоэнергетика. Становится очевидно, что шизоидное расщепление - это очень следствие раннего отторжения и враждебной ненависти, которые породили глубочайшие, причиняющие боль и не поддающиеся пониманию внутренние страдания. В статье предлагаются некоторые соображения относительно шизоидной структуры, проиллюстрированные анализом клинической работы с клиентом. Принимая во внимания, что, согласно теории, шизоид может ощущать взаимодействие, как особенно угнетающую внутреннюю амбивалентность, в данной статье будут представлены соображения о работе с таким клиентом в терапевтической обстановке. 
无尽头的真爱困境: 处理分裂佯矛盾 (Chinese)

Schiz-是一个拉丁词缀，包括了分裂，分隔或者裂缝的意思。schizoid 在德语中，在20世纪20年代 的意思是「类精神分裂症」，来自于希腊语schiz和-oeides相似,来自于eidos，「形式和形状」。 在勒温的书籍《对身体的背叛》，《身体的语言》，《身体动力分析》中，我们可以完整的了解他对 分裂佯人格结构的观点。很明确的一点是分类佯的分裂发生在非常早期的被拒绝和敌意仇恨情景 中，并将引起一种极端深刻又常常到被误解的内在折磨。以下的文章提供了关于一位分裂佯案主 的临床分析工作的思考，在理论层面提出人际互动在此案例中会对案主带来压抑性内在矛盾。此 论文将提供一些在治疗设置中与分裂佯案主工作的思考。

\section{Diagnostic and Psychotherapeutic Processes}

Some of us may be able to see quite a bit of the story in our patient's body, but he, the patient will feel no more of it than what he can tolerate of the pain and shame that broke him in the first place.

Dr. Robert Lewis $(2014$, p. 9)

It was April 7th 2017 and I had just begun working in a new office, two years after graduating as a psychologist and having finished one year as a trainee in Bioenergetic Analysis. Anne had found my card, and told me that she had found many, but the one she liked the most was mine, and so she came to see me. Anne was 20 years old, in the middle of her fourth semester of psychology and lived close to the office with her parents and her sister, who was three years older. Her mom was a teacher at a school close by and her father was an engineer.

Her sister, Lauren, studied sociology, but "she always has a lot of problems. Lately she's dealing with her tooth, she has a black tooth and will undergo surgery. She always has a lot of anxiety, and since there is no space for me to share my problems at home because mine are less important, I'm here." Anne went on without realizing the contradiction: "I talk about everything with my mom and dad, and we have a wonderful relationship". Her face transmits a weary distrust, a look of critical superiority, and behind all of this, a simultaneous look of a young child's despair in a distant and silent void of nothingness.

Anne was split off from herself and from the world and, having no idea of this, she came to me every week, without missing or arriving late for even one session during what has been the better part of two years and still counting. Somewhat different was my first impression: she was sweet, sensitive, kind and clearly longing for contact, and at the same time, harsh, distrustful, defiant, angry and afraid.

The primary reason she came to therapy was her terror of speaking in public. "My vision becomes foggy; I feel my body shake and I begin to sweat." At the 
time, in her second year of college, she was constantly prone to need to interact with other people, and Anne was terrified of interacting with anyone including myself. She continued to share with me about her trouble of presenting works or papers at college and interacting with other people. She often tells me how she suffered bullying at school, she was teased and called names by the boys in her class because of her appearance and because she was much more introverted than any other person she knew at school.

Ever since she has been coming to see me, one of Anne's main topics is how she constantly feels invaded. Her main complaints of invasions were by her teachers and her class colleagues, whom she was never close to. At the slightest sign of any discrete expression of discomfort coming from her interactions with her family members, whether I would ask about it or not, she would quickly and sharply let me know that she has absolutely no problem with her family and that she is blessed to have such a united, present, loving and happy family.

For a long time, she drew a strong line between me, our sessions, and her family system and dynamics. After about six months of our ongoing work, I requested that she bring me some photographs, around five or six of herself and of her family members. The next session she came in, sat down, and told me she did not bring the photographs because this was a request that came from me, and not from inside of her. It was not her authentic desire. I felt that my desire, to see her family, to bring them into our therapeutic setting, had invaded her. I told her I understood and explained that she was right: it was entirely my desire to know her family and see pictures of her childhood.

I told her I wanted to get to know her better but respected that she did not want to bring in pictures and that was fine, I told her she could bring them in whenever and if ever she desired. She smiled and we stayed in silence for a short while, making eye contact. She would smile, timidly, and I would smile back, breathing in synchrony. At the same time I felt worried about having invaded her, I felt joy about being sincere about my intentions and motivations with her, at that moment I felt in my heart and cheeks a fulfilling love and calmness.

Anne is constantly preoccupied with being exposed, hostilely criticized and finally, hurtfully rejected. This preoccupation stresses, feeds Anne's ongoing, fear of, and vigilance to escape being invaded. She felt deeply incapable of being autonomous, taking a bus somewhere, talking to someone she didn't know, sharing almost any information about herself with almost anyone from outside of her family. When I would ask if anything ever made her angry, as she would share her day-to-day interactions in college and at home, and would tell me "not angry, just a little bit uncomfortable."

I felt that her retraction from any other possible relationships, besides with her family members, was her best defence against the terror she felt and the obsessive thoughts that would undermine her available energy and "weigh her down" - she would sometimes complain she felt heavy and couldn't stop thinking. 
One day, Anne arrived feeling sad. She was feeling down and didn't really know why, she told me. She felt a weight in her chest and when she arrived home the night before, she sat to talk with her dad. After telling him she was sad, his response was "Sad? Why? You have everything; we give you everything you could possibly need so you have no reason to be sad. When I was a boy, after my mother died, my dad told me I had to work so I could live in the house, and I did ..."

She proceeded telling me, with absolutely no complaint, that he continued the long story about his harsh childhood, and when he was finished, she said she felt bad about being sad, and was sleepy so she gave him a kiss and went to her bedroom to sleep. I breathed in deeply and I said that it seemed that she was unable to express her feelings to her dad because he talked instead of listening. "I don't see things like that!" she answered irritably. I said "ok" and didn't touch upon the subject again.

The next session Anne came in telling me she was feeling extremely uncomfortable about our last session and about what I had said about her dad. She determinedly assured me that her father listens to her very well and that her entire family is there for her when she needs. "Since this happened, I've decided to take notes on all of our sessions, I want to record everything you say," she said, as she pulled from her backpack a notebook and a pen, opened it on her lap and propped the pen on her fingers as she looked at me.

I felt enormous pressure in my chest, and my insides cringed in shame. I breathed in and out deeply and told her that if this made her feel safe here, it was perfectly fine. It was a constant challenge to find a balance between my own fears and fantasies of invading her with my needs and feelings, of being inadequate or harmful to her, and of the possibility of authentically and lovingly meeting her in her rhythm and possibility of contact. At one point, well after six months of work, frustrated with the avoidance of talking about her story, I mentioned that eventually we would need to talk about her childhood and that that would involve talking about her family. "How does this make you feel, Anne?", I asked. "I don't have any bad memories from my childhood, and I don't see why this is important in our therapy, that's not what I come here to talk about."

When her "discomfort" seemed evident to me, especially in relation to her mother and sister, and sometimes to her dad, I would delicately ask about how she was feeling. She would rationalize the situation and always reach the same conclusion: "I don't think this is a big deal for me to feel this way about it". When I asked her if she ever noticed that she disqualifies her negative feelings very quickly, she was quick to disagree. After a long silence, she told me, "I do understand ... but I really don't know exactly what happens, you know?"

These words exactly represented our first sessions. Anne would spend several minutes in silence looking towards the corner of the room for "exactly the right word" that would attempt to translate and express what she felt. Her desire to show herself to me connected us, she wanted to be here, she wanted to talk to me, 
she wanted to be seen, and it became clearer each day, that she didn't just want me to see her, she wanted me to see what she wanted to show me, and I needed to respect this if I wanted to make genuine contact with her.

Although I rationally understood what I should do, and ended each session thinking to myself, "go slow, let her take you only where and when she is safe", my own fear of contact and rejection would kick in and I would find myself feeling extremely anxious and irritated, sometimes before and sometimes after our sessions.

One day, I had left a small candle lit on my desk inside the office. After another tense session, as Anne got up from the sofa she walked towards the candle, and staring at it, she cuttingly asked, "do you always leave lit candles here? This really scares me, you know?! I'm terrified that things may catch fire." My first instinct was to put out the candle immediately and quickly ask for forgiveness, but I breathed in, observed this impulse in my body, my own insecurity, and the mountain of feeling and cloud of thought that flooded me, breathed out, and contained myself to not do anything to quickly end her discomfort but only to receive what she was telling me. "I understand", I told her. Once she left, I sat and thought about my fear: I felt afraid she would abandon our work together because of the lit candle and I felt extremely wrong and irresponsible.

I had never experienced such resonance with a client before. I had only read about this concept, heard about it in workshops, but I had never consciously felt in my body what my client feels in hers. Empirically, I didn't really know how this felt like. In college I had learned about countertransference, of course, but this was different, and even though I couldn't explain what was happening, I knew there was something profoundly shared with Anne in what I was feeling.

She had made me a serious request, "take care of me." "Please don't hurt me or put me in danger", I could feel her saying this inside my heart as it resonated with my own fears. Since then, before her sessions, I would make sure no candles were lit.

"I'm feeling heavy, again, with really low energy", she told me one day. In one of her classes, she had been assigned a group project and was beginning to plan how she would deal with her terror each step of the way. That must be tiring, I thought to myself.

"I don't really rest," she commented, "my head is always on and working at full throttle." Her unremitting state of being was that of awareness of everything around her. When any little bit of information about her would spontaneously escape her tight hold in a conversation with someone or in a group discussion, she would feel extremely guilty and "heavy". She explained to me that it was as if she was now guilty of having given someone ammunition to invade her with.

She would seldom ask me about bodywork, and whenever I would suggest one, most times, something subtle such as breathing, or grounding, despite accepting, she would continue talking until the session was over. This would frustrate 
me, and I would catch myself thinking that I never did bodywork with her as I inflexibly criticized my therapeutic handling. At the same time, I would remember that we were working in the rhythm she was able to. We were working in a much more subtle, but still energetically intense, respectful way, and that this was bodywork. Little by little I would accept that this was the only way to genuinely and respectfully work with Anne. I would not insist on exercises and if I suggested and she declined, I learned to integrate my feelings of inadequacy, fear and rejection and understand that she was regulating herself in our relationship and that this is intense pre-verbal bodywork.

One day, complaining about the tension in her shoulders and neck, she said to me, "today I want to do a bioenergetic exercise". I asked if she wanted to stand, and she told me she did, so I invited her to stand and experiment with grounding in the arched forward position. We spent a good amount of time going very slow. As she lifted, she told me she felt more at ease and relaxed and that the weight she often complains about had gone away for that moment although her legs were very tired. She shared that she and her sister, Lauren, have had to share a room ever since she was born, and each day when she arrives home, they have profound conversations in their room. She feels that her sister is her best friend and although she enjoys this, she confessed timidly that often the talks feel draining since she listens much more than she is effectively listened to. I remained silent and somewhat surprised with the spontaneousness with which she had opened her negativity to me. Quietly, I breathed and listened. And she went on: "I'm very pensive, quiet and observing, ever since I was little .... I never share my thoughts with anyone, most times they don't seem important enough ..." Looking at each other, quietly, we breathed.

It was very rare that she was able to look me in the eyes for more than a couple of seconds, but this happened more and more as we worked together. Sometimes, when it happens, I feel as if Anne were defying herself to look her fear in the eyes, in a death-defying search for any loving contact. These instants touch me profoundly, and I feel tenderness and love in my heart, in my eyes, in my cheeks and in my arms as I tune into her suffocating struggle to trust me in spite of her fear and need to split off.

Her energy resides almost strictly in her core, from the waist up, and seldom reaches the peripheral parts of her body. Her voice is soft and controlled, and she often shares in our sessions that her throat is narrow and feels tight.

One day, she arrived especially excited because she realized that she had spontaneously expressed herself to a teacher that she particularly admired. The teacher had contradicted herself in two different classes that Anne took and during the second class she raised her hand and denounced the woman's shortcoming. This was very new for Anne. Although it was difficult to express herself, it felt pretty good this time. This teacher received her criticism well, admitting to having done as Anne complained and kindly apologized for her incoherence. Finally, the 
teacher added, "although I understand, and welcome your feelings, I also feel like you are scolding me." I remembered the incident between us involving the candle.

Anne told me that it was not new for her to hear that people think she is scolding them, and although she was happy with how receptive the teacher had been, she kept thinking about her last comment. Other people's interpretations of her, even seemingly positive ones, like that she is "sweet" and "sensitive", are almost all extremely invasive to Anne. She is often interpreted as "brava", as if she were "unacceptably tough", and she does not see herself in this way. She was glad to have expressed herself but, once again, also felt misunderstood and frustrated.

I told her "brava" can also mean "courageous, brave", as it is also an interjection to express congratulations in Italian. She laughed at my interpretation and looked at me with a questioning wonder, such as a small baby observes its mother, and together we laughed. Now, Anne holds on tightly and proudly to being "brava". In some way this became a positive resource for her, maybe one of the first palpable things that came from me that Anne could receive and hold on to. She still brings this into our conversations, when someone at home, like her mother mostly, or her sister, would complain she was "brava". "When she said that I actually felt bad, but I remembered what you told me about courage".

Slowly, we had created minimal room for her family to be talked about during our sessions. As I was beginning to see it, this was a very big step for us. Our work manifestly began to change. She would sit in the office more at ease, move the cushions around to better accommodate her body and began to ask me for a cup of water at the beginning of each and every session. What came from me seemed to be less and less invasive and her profound desire for contact started to become visible. After asking for her water, one day, she said, "I want to talk about my family. It's just that ... sometimes I feel invisible!" she exclaimed, "What about what I feel?! What about when I need to talk!?" (Alluding to her sister) "It's like I have to be in a crisis for someone to notice me!" She explained to me that she felt upset because she arrived home one day, and her sister was having an anxiety attack and asked Anne to be with her. Lauren had called their mother who was coming home from work to be with her as well. Anne's final straw was when her mother asked to speak to her on the phone and told her to not say things that might worsen the situation. I asked if she felt angry, she froze and told me "No!". Once again it seemed to be her dissociating from her fear of her own feelings. Anne has a lot of anger in her body that seems to leak out in the form of moralistic complaints and reprimands, fear and discomfort or rationalized concepts about society.

In the next sessions, Anne shared how she felt severely guilty about having talked about her family to me. Again, I could feel her anger and at this point of our work, I strongly felt that very early Anne had been denied her right to feel anything. She explained that she probably hadn't depicted reality justly enough.

2 "brava" - a Portuguese word. 
"I'm feeling bothered", she said. "I'm irritated with how you make me look at things, I never looked at my family like this." The fear I had felt before returned, I breathed. All I could do was breathe. After this session I found comfort in the words of Dr. Robert Lewis (2014), "Our patients still want us to find them. But when they have been broken and shamed, we must indeed be both wise and gracious to know how to visit them in the inner place where their core grace is shadowed by torment and isolation."

Anne's split is like a constant tearing off from everything in her life. At the same time as she is assailed by terror, she does long for love and human contact. She longs for friends, she now tells me, for "a tribe" but concurrently she needs to keep a distance from anything that may offset the fragile equilibrium between her split-off parts, which are structured under intense pressure to hold together and to hold on. It is as if she longs to be seen, but not looked at, recognized but not interpreted.

At times I feel she is a small baby who has received hostile love, judging love, toxic love, or broken love. Even though she is 21 years old now, she constantly feels entrapped by her ambivalence towards interaction, incapable and afraid, angry and invisible, misunderstood and over-interpreted, unseen and exposed. About two years into therapy, I begin to find that although I can study and conjecture upon her attachment pattern, the reality is, I myself may never know exactly how Anne was seen and loved as a baby. At the end of the day, what seems to matter in the here and now of our sessions is the quality of my presence, and the authenticity of my love for her, as well as the patience to respect her rhythm and her inner ambivalence as a painfully misunderstood state of existence.

"Simply said, you can listen to the wind or to someone's soulful cry, but you cannot grasp, fully comprehend them" (Lewis, 2014, p. 3).

\section{Innovative Clinical Experience}

About one year into our work, Anne came in telling me something had happened in college that she wanted to share, but that she would need to make a long retrospective account in order to be able to tell me. This was common, she would often need to give me many precise details about a situation to then talk about how she felt or what actually happened. As she began her story, I instantly began to feel heavy-eyed, as I had been feeling during our sessions for a few months already. On this day, nonetheless, I dozed off as she spoke and suddenly, she said, "You're sleeping."

I immediately awoke, embarrassed and ashamed, because I in fact was sleeping. Her face conveyed her desolation. I felt as if I had suddenly broken our bond, afraid she would leave, afraid to have hurt her, as if my fantasies had become reality because of my inadequate handling. "You're right, Anne ...I was sleeping", I 
said, "I'm sorry. I'm feeling very tired." She told me she could tell and that she had noticed in the past months that I would become sleepy regularly.

At that time I was working full time as a $3^{\text {rd }}$ grade schoolteacher and our sessions were at night. I told her that I felt ashamed and at the same time thankful that she said something and woke me. What followed was a long, difficult, silence, during which Anne would painfully look to me and away from me.

And so she began to share: "this happens at home ... A lot ... Sometimes I'm trying to tell my parents or grandmother something and I notice that they begin to fall asleep or are not interested. This makes me feel uninteresting, like I'm transparent ... I feel insignificant." I asked her what she does when this happens, and she told me she usually tells them the same thing she told me. "What do they say?" I asked. "They deny it. They always say that 'of course not!' and that they are paying attention, but I know it's not true ..."

She brought this topic in again on our next session. She told me she felt sad about what happened. I listened quietly as she told me she feels that many people are indifferent to her existence, schoolteachers, family members, and colleagues from her old schools where she was not only bullied for many years but never able to make friends. I listened and felt guilty, with an impulse to explain myself once again, tell her I was working two jobs, and desperately try to repair our bond making my error smaller or justifiable. But the truth is that in the moment I fell asleep, I had been unsuccessful at being present with her. I also realized that I had hit the wall of my own narcissistic expectations of myself as a therapist. Now, I had to be truthful with Anne and with myself. She was letting me know our bond was important to her; she was pulling me close to her the only way she knew how. All I could do was listen and feel touched by her sadness now inside my own body.

Consequently, although I feared my failing would destroy whatever therapeutic bond we had constructed, what happened was the opposite. I now felt closer than ever to Anne, and I never fell asleep or felt uncontrollably sleepy again in our sessions.

Little by little, throughout the years, with many ups and downs, Anne and I continue to stitch together a secure bond. She has a deep need to be listened to and respected. She has very little identification with her body and a chronic sensation of insecurity. Cautiously but willingly, she now complains that her family over-protects and infantilizes her, and that it is invasive, and it irritates her.

Anne slowly and very carefully lets me see her anger in shy appearances of irritation that I will carefully ask about. When I ask her if there is any feeling present in her body, she takes her time to perceive herself, closes her eyes, breathes in, out, and tries to name her feelings out loud. Laughing she exclaims: "you always make me do this!" and her eyes brighten playfully. Smiling she sometimes looks to the ceiling, "I'm not sure if it's anger ... I did feel irritated ... or better, bothered". Although at a first glance, this may seem minor or insignificant, for Anne, it is a sign of meaningfully arduous work. There seems to be more space for anger now. 


\section{Applicability and Validity for Other Clinicians}

There is considerable literature that throws light on Anne's condition. Bleuler (1976) first coined the term "schizoid" in 1908, describing people with schizoid features as shut-in and suspicious, while simultaneously sensitive and in pursuit of purposes. In his view, these ambivalent characteristics appeared in the pre-psychotic personality of schizophrenic illness. Although the schizoid structure is not a disorder and does not always lead to a psychotic state, as was widely believed in Bleuler's time, he demonstrates in his description that the schizoid split creates a clear a duality.

In Martens' (2010, p. 38) study, he describes the feelings of "unbearable and inescapable loneliness" lived by schizoid-structured individuals as intense, sometimes distorting moments of physical and emotional suffering. The schizoid split is an eternal tear-in-two that leaves great emotional lacerations that hold and sometimes exude extraordinarily painful states.

The intensity of the way this is felt by a person is not always easily evident to family members, friends, nor also, to therapists. Due to a person's apparent detachment and sometimes-subtle hostility, they are often liable to be misunderstood, unless they explode, which may occur and also not be understood as an unplanned eruption of intense inner suffering.

According to Thyslstrup and Hesse (2009, p. 156) schizoid ambivalence refers to contrasting feelings in patients of a seemingly emotionally detached appearance that may disguise an inner heightened sensitivity and longing for closeness. In their study, they evidenced: "[a client]'s therapy was terminated for lack of results", from their observations, "he was not able to make the staff members feel that his problems were sufficiently urgent to warrant their help".

Lowen (1979, p. 270) teaches us that the schizoid problem has its origins in the ambivalence the mother feels towards the child in the first moments of its existence. According to Lowen, at the same time that she wants the child, she also doesn't and her attitude towards him changes according to the tensions in her outside life. Her feelings of hostility and gestures of rejection, in one moment, are followed by a sudden need for the child in the next. All of this is not motivated by the child, but by the mother's representation of maternity and therefore of the child. The representation is rooted in the mother's narcissistic illusion that she will feel fulfilled in this role. Her consequential lack of attunement with her baby configures a situation of hostile rejection and threatening invasion to a baby who, at the same time, seems to be sensibly invisible. Her distance and sparse ability to connect with her child translates as rejection and hatred, creating in this child an insufficiency in his or her existence as well as an enormous fear to reach out as this leads to contact with feelings he is not yet able to process.

In response to the fear of annihilation generated by the hatred he receives, what Lowen (1977, p. 342) refers to as "murderous rage" is provoked in this child, 
a feeling intolerable and therefore threatening for his young body. The dissociation from his body and from reality at this tender time ensures his own survival from this traumatic bond.

Besides the fact that the dissonant relationship does not offer security, the little one still has to defend himself against a caretaker who has large unstructured portions of their ego and can be unpredictably invasive. (Weigand, 2005)

According to Baum $(2017 ; 2018)$ the necessary relationship of passivity between the mother and infant, respectful, quiet, warm love, is subverted into an active relationship where the mother's feelings, rooted in her own illusions and projections, invade the baby and in return, his body needs to actively defend itself: the core of the body tightly wraps in the heart and vital organs, away from contact with the outside and with the other.

As Kalsched (1996, p. 229) puts it, once the defence against this trauma is organized, all the relations with the outer world are assessed by what he refers to as a premature self-care system. This way, what was meant to be a defence against further trauma becomes an essential resistance to all unprotected and spontaneous expressions of the self in the world.

This energetic dynamic is encrypted in the matrix of the infant and carried on throughout all of his life. What is intentionally a defence becomes a sort of transparent cage, which, quite paradoxically, does not protect the body nor provide it with any feeling of safety or shelter; it only works to keep strictly locked in, and barely under control, a mortifying and monstrous fear that does not annihilate his need and desire to be seen and loved.

In Anne's case, a great fear, much more so than being rejected, was that of losing her mind. She would not talk about this often, but at times in our sessions, as she would tell me about her feelings, the more she was able to express negativity towards her family, this fear would appear in the form of guilt and confusion as well as ambivalence. Seeing her shuffling through her thoughts as she would hold her head in her hands, I would sometimes ask her if she fears going crazy. My question was always received with a wide-eyed startle and a vigilant nod as if not to unwrap anything too much. Anne lives entrapped in a delicately fragile stronghold.

In Thyslstrup and Hesse's (2009, p. 148) study they state that Bleuler indicated the intrapsychic dynamics of ambivalence in schizoid disorder, and it has been discussed in later literature on psychopathology.

Bleuler (1976) argued that ambivalence was a consequence of the contrasting associations his patients with schizoid personality disorders (SPD) suffered, and that this often challenged clinicians because of client's seemingly detached and restricted affective behavior, which may be interpreted as lack of motivation for treatment and lifestyle changes. According to him, the ambivalence is representing a tendency to experience contrasting feelings (affective ambivalence), intentions (ambivalence of the will), and thoughts (intellectual ambivalence) to 
situations, objects or people, for example, experiencing love and hatred for the same person.

Lowen (1982, p. 302) explains that facial expression of the schizoid client can seem to transmit indifference, maybe arrogance, or simply be expressionless, like a mask that hides un-feelable terror.

\title{
Contribution to the Development of Clinical Bioenergetics
}

\begin{abstract}
"As healers, we each have our own mix of capacities for autonomy and intimacy, also known as our preferred attachment style. [...] The challenge for [...] all healers with relational wounds, is to know when we are pulling for the patient's vulnerability and authenticity mainly for his sake, and when our own unresolved need to be deeply valued has gotten out of hand, such that we are trying too hard" (Lewis, 2009, p. 6).
\end{abstract}

Perhaps we can benefit from being very careful in detecting and naming our counter-transference, in being aware of our irrational expectations, narcissistic frustration and anger in the relationship with this type of client in order to not reedit a relationship with an ambivalent, available but unavailable caretaker.

When I thought about Anne's case, sometimes I would feel frustrated that there was so little change. It was arduous work in supervision and in my own personal therapy around my own fears, projections and narcissistic expectations of my own work and consequentially of my patients.

Although they remain virtually untranslatable into words, Anne has very clear terms of how she wants to be treated by me. Whenever talking about her parents I have to be very attuned and delicate. My interventions are almost always felt as violent invasions, but at the same time, she continues coming, and inevitably, intentionally or not, I continue intervening.

Above all, so she can support our bond, it is important for her to be sure that she could push me away and pull me back as she needed. I need to be clear that I will not go away because of this, I will not take my love away and the only reason is: I do not want to go away. In Guest's (2017) words, "we cannot love someone we are afraid of", and I dare to add: "we cannot feel loved if we are afraid."

While I am afraid of Anne, she will be afraid of me. While I am afraid she will reject me, so will she. Once I am able to authentically open myself to receive whatever she can show, even to her rejection, I am able to open myself to feel love for her, and so, be able to patiently and lovingly walk beside her as she finds her own, genuine, rhythm and direction.

Our relationship exists not despite, but through means of a barrier that must be respected, in spite of the fear, in spite of the anger. Little by little we strengthen a common understanding that I will not betray her, however, the only way to 
have this understanding is by means of a previous one: she can push me away and pull me in as much as she needs, and I will not hate her. This is established in our relationship, so she is free to live out and actively express her ambivalence. Her coming and going, the limits she bravely gives me, her acute attention to anything that I am doing different, are not gestures of cruelty, or simply of anger that need to be cathartically expressed. They are underlying energetic attempts to stitch together a minimal security nest necessary for her to make long desired, but yet greatly feared, contact with another human. The duality that tears her experience of living until this day may quite possibly do so as long as she lives, but any possibility of contact, as small as it may seem, offers her an authentic moment of recognized existence.

Anne does not come to my office so I can do a good job as a therapist, or so I can help her become someone else. Some days it dawns upon me that Anne comes to my office to be loved and accepted, to be minimally safe for at least one hour in her week, to be looked at and not be judged, and to feel herself existing. There is realistically not much technique that needs to consciously come into action in our sessions for this to happen; there are no big expressive exercises that can give this to her.

In Anne's sweet and sour attitude she gradually gains the security she needs to let me come closer, and so she as well, can unveil herself to me and ultimately, to herself.

\section{References}

Baum, S. (2017, 2018). KeyNote Address. IIBA Conference, Toronto, Canada, May 2017. Talk. SABERJ, Rio de Janeiro, September, 2018.

Bleuler, E. (1976). Textbook of Psychiatry. New York, NY: Arno Press.

Guest, D. (2017). Workshop. SABERJ, Rio de Janeiro. August $11^{\text {th }} 2017$.

Kalsched, D. (1996). The Inner World of Trauma: Archetypal Defenses of the Personal Spirit. London: Routledge.

Lewis, R. (2003). The Anatomy of Empathy. Bioenergetic Analysis, 15, 9-31.

Lewis, R. (2004). Human Trauma. Retrieved from https://bodymindcentral.com/publications Lewis, R. (2009). Not Knowing is the Royal Road to Feeling Both a Shameful Fool and Creative Healer. Retrieved from https://bodymindcentral.com/publications

Lewis, R. (2014). Broken and Veiled in Shame; Revealed by the Body's Implicit Light. Retrieved from https://bodymindcentral.com/publications

Lowen, A. (1977). O corpo em terapia: a abordagem bioenergética. São Paulo: Summus.

Lowen, A. (1979). O corpo traído. São Paulo: Summus.

Lowen, A. (1982). Bioenergética. São Paulo: Summus.

Martens, W. (2010). Schizoid personality disorder linked to unbearable and inescapable loneliness. The European Journal of Psychiatry, 24(1), 38-45. 2010. Retireved 10 May, 2018, from http://scielo.isciii.es/pdf/ejpen/v24n1/original4.pdf 
lana Carolina Maciel Franza

ThysIstrup, B., \& Hesse, M. (2009). I Am Not Complaining - Ambivalence Construct in Schizoid Personality Disorder. American Journal of Psychotherapy, 63(2), 147-167. Retrieved 10 March, 2018, from https://www.questia.com/library/journal/1P3-1825357971/i-am -not-complaining-ambivalence-construct-in-schizoid

Weigand, O. (2005). Grounding na análise bioenergética: uma proposta de atualização. Dissertação de Mestrado. Departamento de Psicologia Clínica, Pontifícia Universidade. Rio de Janeiro.

\section{About the Author}

Iana Carolina Maciel Franza is a Psychologist and Trainee in Bioenergetic Analysis (SABERJ) in Rio de Janeiro.

iana.fr@hotmail.com 